\title{
IbM-PELATIHAN TEKNIK PENULISAN PARAFRASE UNTUK SKRIPSI MAHASISWA SEBAGAI UPAYA MENGHINDARI PLAGIARISME
}

\author{
Widya Ais Sahla ${ }^{1}$, Nurul Mukhlisah², Julkawait ${ }^{3}$ dan Rusman Irwansyah ${ }^{4}$ \\ Prodi D3 Akuntansi Politeknik Negeri Banjarmasin ${ }^{1234}$ \\ Corresponding author: ais.sahla@akuntansipoliban.ac.id ${ }^{1}$
}

\begin{abstract}
The issue of plagiarism is one of the issues that gets great attention among the academic world and is our common concern. As a manufacturer of science, Higher Education has a big responsibility to provide education and socialization related to the prevention of plagiarism. The initial conditions of our partners (students of the Islamic Economics Study Program, Faculty of Islamic Studies, Kalimantan Islamic University, Syeh Muhammad Arsyad Al-Banjari), are having difficulties in avoiding the culture of copypaste in completing their academic assignments, especially in doing thesis.

Most students still do not understand the term plagiarism and how to avoid it. After going through community service activities under the title "Training of Paraphrasing Techniques for Writing Student Thesis as an Effort to Avoid Plagiarism" which we carried out on September 22, 2018 then our partners can apply good paraphrasing techniques to avoid plagiarism.
\end{abstract}

Keywords: plagiarism, paraphrasing, UNISKA.

\begin{abstract}
ABSTRAK
Isu plagiarisme menjadi salah satu isu yang mendapat perhatian besar di kalangan dunia akademik dan menjadi keprihatinan kita bersama. Sebagai produsen ilmu pengetahuan, Perguruan Tinggi memiliki tanggungjawab yang besar untuk memberikan edukasi dan sosialisasi terkait dengan pencegahan tindakan plagiarisme. Kondisi awal mitra kami (mahasiswa program studi Ekonomi Syariah Fakultas Studi Islam Universitas Islam Kalimantan, Syeh Muhammad Arsyad Al-Banjari) yaitu mengalami kesulitan dalam menghindari budaya copy-paste dalam menyelesaikan tugas akademiknya terutama dalam mengerjakan skripsi.

Sebagian besar mahasiswa masih belum memahami istilah plagiarisme dan bagaimana cara menghindarinya. Setelah melalui kegiatan pengabdian kepada masyarakat dengan judul "Pelatihan Teknik Parafrase untuk Penulisan Skripsi Mahasiswa sebagai Upaya Menghindari Plagiarisme" yang kami laksanakan pada 22 September 2018 lalu mitra kami dapat mengaplikasikan teknik parafrase yang baik guna menghindari plagiarisme.
\end{abstract}

Kata kunci: plagiarisme, parafrase, UNISKA. 


\section{PENDAHULUAN}

Isu plagiarisme menjadi salah satu isu yang mendapat perhatian besar di kalangan dunia akademik. Hingga saat ini telah muncul beberapa kasus plagiarisme yang menjadi keprihatinan kita bersama. Tahun 2004 Menteri Kesehatan Siti Fadilah Supari dituduh melakukan plagiasi ketika menyajikan seminar di Pusat Jantung Harapan Kita pada Oktober 2002. Beliau menyampaikan bahan seminar yang mirip dengan karya James W Anderson yang telah dimuat pada American Journal of Clinical Nutrition volume 71 tahun 2000. Pada tahun 2014 Anggito Abimanyu dianulir melakukan auto plagiarism yang kemudian berujung pada kemunduran diri beliau sebagai akademisi Universitas Gadjah Mada. Serta banyak lagi kasus plagiarisme yang mendera tokoh-tokoh akademisi di negeri ini.

Plagiarisme terjadi ketikaseorang penulis mengambil karya intelektual seperti gagasan, pendapat, temuan, simpulan, data, kalimat dan kata-kata orang lain sehingga pembaca menganggap bahwa karya intelektual itu merupakan karya penulis tersebut (Kramer, 1995); (Wray, 2006). Plagiarisme muncul sebagai konsekuensi dari semakin terbukanya informasi melalui internet dan media sosial. Dimanapun dan kapanpun kita dapat memperoleh informasi yang dibutuhkan, termasuk memperoleh referensi dalam penulisan karya tulis ilmiah. Akan tetapi, kemudahan tersebut belum disertai dengan kesadaran literasi yang baik. Etika copy-paste atau pengutipan sumber informasi belum menjadi hal yang diperhatikan dalam budaya akademik terutama oleh mahasiswa.Tidak sedikit mahasiswa yang seenaknya dalam melakukan copy-paste yang berasal dari internet dalam mengerjakan tugas akademiknya. Budaya copy-pasteini seolah sudah menjadi rahasia umum di kalangan mahasiswa. Apabila hal ini terus dibiarkan maka akan semakin meningkatkan budaya plagiarisme.

Perguruan Tinggi memiliki tanggungjawab yang besar untuk memberikan edukasi dan sosialisasi terkait dengan pencegahan tindakan plagiarisme. Hal ini mengingat perguruan tinggi merupakan salah satu produsen ilmu pengetahuan. Untuk mengatasi meluasnya permasalahanplagiarisme di dunia akademikdi Indonesia, pemerintah sebenarnya telah membuat peraturan menyangkut sanksi bagi pelaku tindakan plagiarisme. Berdasarkan UU No. 20 tahun 2003 dinyatakan bahwa sanksi atas tindakan plagiarisme dalam persoalan karya tulis sebagai berikut. Lulusan PT yang karya ilmiahnya digunakan untuk memperoleh gelar akademik, profesi, atau vokasi, terbukti merupakan jiplakan, dicabut gelarnya (pasal 25 ayat 2). Lulusan yang tersebut pada pasal 25 ayat 2 dipidana dengan pidana penjara paling lama dua tahun, dan atau pidana denda paling banyak Rp. 200.000.000,- (dua ratus juta rupiah). (Zalnur, 2012).

Mahasiswa program studi Ekonomi Syariah Fakultas Studi Islam Universitas Islam Kalimantan, Syeh Muhammad Arsyad Al-Banjari (UNISKA) yang menjadi 
mitra dalam rencana kegiatan pengabdian kepada masyarakat tahun ini berlokasi di Kampus UNISKA Jl. Adhyaksa No.2 Kayutangi Telpon : 0511-3304352 FAX : 0511-3305834 Email: admin@uniska-bjm.ac.id. Kondisi mitra saat ini yaitu mengalami kesulitan dalam menghindari budaya copy-paste dalam menyelesaikan tugas akademiknya terutama dalam mengerjakan skripsi. Sebagian besar mahasiswa masih belum memahami istilah plagiarisme dan bagaimana cara menghindarinya.

Melalui kegiatan pengabdian kepada masyarakat dengan judul "Pelatihan Teknik Penulisan Parafrase untuk Skripsi Mahasiswa sebagai Upaya Menghindari Plagiarisme" ini kami berharap anggota civitas academica terutama mahasiswaprogram studi Ekonomi Syariah UNISKA mampu menghasilkan karya tulis yang berkualitas dan terhindar dari unsur plagiarisme. Sehingga ke depannya tidak perlu ragu-ragu ketika menyusun Skripsi menyebutkan sumber rujukan. Karena hal ini merupakan kejujuran intelektual yangtidak akan menurunkan bobot karya tulis kita.

\section{PERMASALAHAN MITRA}

Permasalahan mitra yang ingin diselesaikan antara lain:

a. Budaya copy-paste yang masih lazim digunakan dalam menyelesaikan tugas kuliah dan skripsi;

b. Belum memiliki pemahaman yang jelas mengenai plagiarisme dan sanksi yang melekat di dalamnya.

\section{TUJUAN DAN MANFAAT KEGIATAN}

Tujuan dan manfaat kegiatan ini yaitu dalam rangka memecahkan permasalahan mitra yaitu:

1. Memberikan pemahaman dan gambaran yang jelas mengenai plagiarisme di dunia akademik dan hal-hal apa saja yang terkait dengan isu plagiarisme termasuk juga sanksi yang melekat di dalamnya.

2. Memberikan penjelasan mengenai parafrase sebagai salah satu cara menghindari plagiarisme dan menghilangkan budaya copy-paste mahasiswa.

3. Memberikan pelatihan teknik parafrase kepada mahasiswa sebagai peserta sehingga mereka dapat mempraktikkannya pada Skripsi yang sedang mereka kerjakan.

\section{TINJAUAN PUSTAKA}

\section{Definisi Plagiarisme}

Menurut Peraturan menteri Pendidikan Republik Indonesia No 17 tahun tahun 2010 khususnya dalam BAB I Mengenai ketentuan Umum Pasal 1, definisi 
plagiarisme adalah "perbuatan sengaja atau tidak sengaja dalam memperoleh atau mencoba memperoleh kredit atau nilai karya ilmiah, dengan mengutip sebagian atau seluruh karya dan/ atau karya ilmiah pihak lain yang diakui sebagai karya ilmiahnya, tanpa menyatakan sumber secara tepat dan memadai”.

Sedangkan menurut Reitz dalam Online Dictionary for Library and Information Science (http://www.abc-clio.com/ODLIS/odlis_p.aspx) plagiarisme adalah: "Copying or closely imitating take work of another writer, composer etc. without permission and with the intention of passing the result of as original work".

Berdasarkan dua pengertian di atas kita dapat menyimpulkan bahwa plagiarisme merupakan tindakan baik disengaja maupun tidak disengaja mengakui karya orang lain sebagai karya ilmiah diri sendiri.

\section{Jenis-Jenis Plagiarisme}

Menurut Soelistyo (2011) terdapat beberapa jenis plagiarisme, yaitu:

1. Plagiarisme Kata demi Kata (Word for word Plagiarism).

Jenis plagiarisme ini banyak dilakukan pada karya ilmiah yaitu dengan karya orang lain kata demi kata tanpa menyebut sumbernya.

2. Plagiarisme atas sumber (Plagiarism of Source).

Penulis menggunakan gagasan orang lain tanpa memberikan pengakuan yang cukup (tanpa menyebutkan sumbernya atau referensinya secara jelas).

3. Plagiarisme Kepengarangan (Plagiarism of Authorship).

Penulis mengakui sebagai pengarang karya tulis karya orang lain. Tindakan ini terjadi atas dasar kesadaran dan motif kesengajaan untuk membohongi publik.

4. Self Plagiarism.

Self plagiarism merupakan tindakan mengambil karya sendiri sebagai bagian dari karya yang baru. Plagiarisme jenis ini tergolong menjebak karena biasanya penulis tidak menyadari telah melakukan self plagiarism. Menurut Henry Soelistyo (2011: 21-22) self plagiarism atau auto plagiarism adalah bentuk plagiat dengan melakukan penggandaan, penduplikasian karya sendiri untuk beberapa kepentingan. Misalnya, seorang mahasiswa yang mengumpulkan tugas dengan karya yang sama pada dua atau lebih mata kuliah yang berbeda.

\section{Parafrase sebagai Pencegahan Plagiarisme}

Terdapat beberapa cara dalam menghindari plagiarisme yang tertuang dalam Permen Diknas No. 17 Tahun 2010 Pasal 7 yaitu: 
1. Karya mahasiswa (skripsi, tesis dan disertasi) dilampiri dengan surat pernyataan dari yang bersangkutan, yang menyatakan bahwa karya ilmiah tersebut tidak mengandung unsur plagiat dan dibubuhkan materai di atas tanda tangannya.

2. Pimpinan Perguruan Tinggi berkewajiban mengunggah semua karya ilmiah yang dihasilkan di lingkungan perguruan tingginya, seperti portal Garuda atau portal lain yang ditetapkan oleh Direktorat Pendidikan Tinggi.

3. Sosialisasi terkait dengan UU Hak Cipta No. 19 Tahun 2002 dan Permendiknas No. 17 Tahun 2010 kepada seluruh masyarakat akademis.

Namun, selain bentuk pencegahan yang tertuang dalam Permen tersebut, terdapat langkah yang dapat menghindarkan diri kita dari plagiarisme yaitu melakukan pengutipan dan parafrase.

Parafrase adalah mengungkapkan ide/gagasan orang lain dengan menggunakan kata-kata sendiri, tanpa merubah maksud atau makna ide/gagasan dengan tetap menyebutkan sumbernya. Berikut ini adalah 6 teknik menulis efektif dalam melakukan parafrase seperti yang diberikan oleh panduan OWL Purdue (https://owl.english.purdue.edu/owl/resource/619/1/):

1. Bacalah kembali teks sumber sampai kita memahami benar isi teks tersebut.

2. Singkirkan teks/naskah asli tersebut dan tulislah ulang gagasan dalam teks tadi dalam sebuah kertas.

3. Buatlah daftar beberapa kata dibawah parafrase kita tadi untuk mengingatkan kembali pada cara kita memahami naskah asli tersebut. Di atas kartu catatan tadi, tuliskan kata kunci yang menunjukkan subjek atau tema parafrase kita.

4. Bandingkan tulisan parafrase kita tadi dengan naskah aslinya untuk mengecek apakah semua gagasan, terutama gagasan yang penting telah tercantum dalam hasil parafrase tersebut.

5. Gunakan tanda petik ganda untuk mengidentifikasi istilah-istilah khusus, terminologi, atau frase yang Anda pinjam dari naskah asli, dan yang kita ambil sama pesis dengan naskah asli.

6. Tuliskan sumber (termasuk halaman) pada kertas catatan kita sehingga ini mempermudah kita untuk menuliskan sumber pustaka atau referensi, bila kita bermaksud mengambil parafrase tersebut.

\section{METODE PELAKSANAAN}

Pelaksanaan kegiatan pengabdian kepada masyarakat dilaksanakan pada hari Sabtu tanggal 22 September 2018 bertempat di ruang T6 Jurusan Akuntansi Politeknik Negeri Banjarmasin. Adapun jumlah peserta yang hadir sebanyak 19 orang mahasiswa dari Program Studi Ekonomi Syariah Fakultas Studi Islam 
UNISKA Banjarmasin. Kegiatan ini juga dihadiri oleh dosen dari Program Studi D3Akuntansi Politeknik Negeri Banjarmasin.

Metode pelaksanaan pengabdian kepada masyarakat ini yaitu dengan memberikan materi dengan judul "Plagiarisme dan Parafrase dalam Karya Ilmiah" yang disampaikan oleh Bapak Dwianto Mukhtar Latif, M.Sc sebagai narasumber dari Fakultas Ekonomika dan Bisnis Universitas Lambung Mangkurat.

Setelah penyampaian materi, peserta dipersilakan untuk menyerahkan file proposal skripsi mereka untuk diuji plagiasi oleh narasumber. Pada kesempatan tersebut diperlihatkan hasil uji plagiasi dan mereka bersama-sama berlatih bagaimana membuat parafrase dari kalimat yang dinilai mengandung unsur plagiarisme.

Kegiatan pengabdian kepada masyarakat ini juga melibatkan peran mahasiswa. Adapun mahasiswa yang terlibat yaitu: Syiva Humairo dari kelas 5B Prodi D3Akuntansi, Aisyah Rizkya dari kelas 5B Prodi D3Akuntansi, Dina Emelda dari kelas 5A Prodi D3Akuntansi dan Muhamad Rizal Sugianto dari kelas 5A Prodi D3Akuntansi.

\section{KESIMPULAN DAN SARAN}

Isu plagiarisme yang melanda dunia akademik harus mampu dijawab dengan berbagai cara penanggulangannya, salah satunya melalui teknik parafrase yang dapat menghindarkan dari kegiatan plagiasi baik yang disengaja maupun yang tidak disengaja. Mahasiswa sebagai salah satu bagian dari dunia akademik tentu juga sering bersentuhan dengan plagiarisme baik dalam mengerjakan tugas hingga menulis Skripsi. Melalui kegiatan Pengabdian kepada Masyarakat ini, kami telah memberikan wawasan dan ketrampilan kepada mitra kami yaitu Mahasiswa Prodi Ekonomi Syariah UNISKA Banjarmasin dalam melaksanakan teknik parafrase sehingga terhindar dan terbebas dari plagiarisme.

Adapun saran yang dapat kami sampaikan yaitu:

1. Setelah melalui pelatihan ini, kami berharap mitra dapat mengaplikasikan wawasannya dalam melaksanakan teknik parafrase untuk menyelesaikan Skripsi.

2. Apabila pihak mitra bersedia, kami berharap dapat mendampingi mereka saat penulisan Skripsi dalam hal penerapan teknik parafrase.

\section{UCAPAN TERIMA KASIH}

Ucapan terima kasih kami sampaikan kepada Politeknik Negeri Banjarmasin melalui Pusat Penelitian dan Pengabdian Kepada Masyarakat (P3M) yang telah memberikan dukungan moril terlebih materiil sehingga Pengabdian kepada Masyarakat ini dapat berjalan dengan baik. 


\section{DAFTAR PUSTAKA}

Kramer, Melinda G., Gleen Leggett, dan C. David Mead. 1995. Handbook ForWriters. New Jersey: Prentice Hall.

Soelistyo, H. (2011). Plagiarisme: Pelanggaran Hak Cipta dan Etika. Penerbit Kanisius.

Wray, Alison dan Alleen Bloomer. 2006. Projects in Linguistics: Practical Guide to Researching Langguage. Oxfore University Prees.

Zalnur, Muhammad. 2012. Plagiarisme di Kalangan Mahasiswa dalam Membuat Tugas-Tugas Perkuliahan pada Fakultas Tarbiyah IAIN Imam Bonjol Padang. Jurnal Al-Ta'lim, Jilid 1 Nomor 1. 